\title{
Identification of Tomato Seed Pathogens (Fungi) of Different Cultivars and Varieties in Maiduguri Borno State
}

\author{
Shehu I. B., Kharall A., Makinta B. \\ Department of Agricultural Technology, Ramat Polytechnic Maiduguri Borno State Nigeria
}

\begin{abstract}
Article Info

Volume 8, Issue 3

Page Number: 549-554

Publication Issue :

May-June-2021

\section{Article History}

Accepted : 20 June 2021

Published: 30 June 2021

The experiment was conducted in the pathology of department of crop protection univesity of Maiduguri Borno state. Which is located at latitude $11051 \mathrm{~N}$ and longitude $13^{0} 15 \mathrm{E}$ to exermine or to isolate and identified the fungi pathogen responsible for damaging same tomatoes cultivars (Solanum lycopersicon) seed in maiduguri Borno state.The result show that the improve variety of tomatoes seed has number of fungal isolation in the sample where the fungal include Aspergillus niger, fusarium spp, penecillium spp .Whereby in the cullum, the Aspergillus were present. Just less in the following treatment T1(Rio grand), T2(Tema), T3(Uc-82B) Compared to that of fungal pathogen isolate in the local sample which are present T1(Seria dan zang), T2(Dan gashua), T3(Roman dan mazar), T4(Dan jino). Whereas in the Fusarium spp in the improved variety sample the fungal are present in T1(Rio grand), T2(Tema), T3(Uc -82B), and T5(Roa savannah) while in local variety sample the fungal pathogen are present in T1(Seria dan zang), T3(Roman dan mazar), T4(Dan jino) and T5(Utc) where in penilluim spp the fungal are present in the improve variety in T1(Rio grand), T2(Tema), T3(Uc82B), and T5(Roma savannah) compared to that of the local variety sample which are in T2(Dan gashua), T3(Roman dan mazar) and T5(Utc) (Table1). Whereas in the mean disease index recorded on improved cultivars tomatoes. The result shows that T1with (98.14\%) are recorded the highest index followed by T2(Tema) with $(93.10 \%)$ while the least was recorded on T4(Roma vf) with (46.21\%). (Table2) compared to that of local variety sample where by the highest disease index was recorded in T3(Roman dan mazar) with (100\%) and the least was recorded on T1(Seria dan zang) with (97.23) and the least was recorded T4(Dan jino) with (92.26)(Table3).

Keywords : Tomato, Pathogens, Fungi
\end{abstract}

\section{INTRODUCTION}

Tomato (Solanum lycopersicon) mill. Is one of the important vegetable crop which contains some important minerals, vitamins, antioxidant and has high nutritional value. It is widely grown in almost all countries of the world due to its adaptability to a wide range of soil and climate. Tomato is now eaten freely

Copyright: () the author(s), publisher and licensee Technoscience Academy. This is an open-access article distributed under the terms of the Creative Commons Attribution Non-Commercial License, which permits unrestricted non-commercial use, distribution, and reproduction in any medium, provided the original work is properly cited 
throughout the world, and their consumption is believed to benefit the human among other things. However, yield $(\mathrm{kg} / \mathrm{ha})$ in the small holder sector are relatively low compare to large scale commercial. Disease of tomato is among the main factors limiting its production. Over 200 diseases have been recorded to affect the tomato plant in the world (Wattersun, 2008). Among them the seed borne pathogen plays a better role in disease development (Mortenson and Magabaa, 2012). Seed borne disease create loss to the production of tomatoes. Seed plays a better role in the production of healthy crop. They are carrier of most important seed borne diseases caused by microorganism which resulting in considerable losses in yield. Majority of small holder farmers (90-100\%), as a result of inadequate resources, really on farm retain seeds for planting of crops like beans, tomatoes, groundnut, millet and sorghum (Hack, 2005). Since infection can separate very rapidly under suitable weather condition, low levels of seed borne infection inoculum can resulting in severe epidemic and this is especially a problem with tomatoes from infection transplanted (Watterson, 2008). Many workers have reported isolation of various fungi from vegetable seed (Abdel-Mallek et al., 2005). Some of the seed borne fungi were found to be very destruction which causes seed rot, and decrease seed germination. Also, causes pre and post germination death (Abdel-Mallek et al., 2009). Seed fungi are however easily control compares to airborne or soil fungi (Umesha, 2006). The important of seed borne pathogen to crop quality and quantity cannot be ignored. Early identification of plant of plant pathogen in an area allows for early and timely development of control and management strategies that goes a long way in avoiding and crop losses. At the same time laboratory screening of seed for sowing is a cheapest and effective mean of checking the separation of pathogen.

\section{METHODOLOGY}

The experiment was conducted in the Pathology laboratory of Department of crop protection, University of Maiduguri, Borno State. It is located at latitude $11^{051 \mathrm{~N}}$ and longitude $13015 \mathrm{E}$, it lies in semi arid region of Nigeria. Within 3-4 months. With an annual rainfall from $300 \mathrm{~mm}-650 \mathrm{~mm}$.Temperature and relative humidity at $35-36^{\circ} \mathrm{C}---25-30 \%$

\begin{aligned} & \multicolumn{2}{c}{ Materials } \\ & i. Tomato seed \\ & ii. Washing plates \\ & iii. Petri Dish \\ & iv. Distilled water \\ & v. Knife \\ & vi. Drying plates \\ & vii. Culture plates \\ & viii. Tissue paper \\ & ix. Masking tape \\ & x. Marker \\ & xi. Microscope \\ & xii. Incubator \\ & xiii. Wire loop \end{aligned}

\section{Fungi Isolation}

Forty gram $(40 \mathrm{~g})$ seeds were obtained at certified seed vendor at Monday market here in Maiduguri, the seed were sterilized by sodium hypo chloride $(1 \% \mathrm{v} / \mathrm{v}$ for 5 mins). Then 50 seed were counted on each variety and placed on petri dish to germinate. All cultured petri dishes were incubated at $25 \pm 2^{0 \mathrm{c}}$ for $5-7$ days(Michael, 2000). Percentage of number of seed germinated and development of fungal spore appeared on seed will be taken using the following formula.

SGP $=\frac{\text { Number of germinated plant }}{\text { Number of seed placed on the petri dish }}$

Where SGP $=$ Seed Germination Percentage Rate on fungus spp. 


\section{Data Analysis}

Analytical tools used was descriptive statistic and subject to one analysis of variance (ANOVA) using statistix 8.0 and then the means differences were separated using least significance difference (LSD) at $5 \%$ level of probability.

\section{RESULTS AND DISCUSSIONS}

Table 1 : Number of fungi isolate in sample of Tomato seed

Sample (A) Improve $\quad$ Aspergillus_Niger Fusarium spp penicillium spp

$\begin{array}{llccc}\mathrm{T}_{1} & \text { Rio grand } & + & + & + \\ \mathrm{T}_{2} & \text { Tema } & + & + & + \\ \mathrm{T}_{3} & \mathrm{Uc}-82 \mathrm{~B} & - & + & + \\ \mathrm{T}_{4} & \text { Roma vf } & + & - & + \\ \mathrm{T}_{5} & \text { Roma savannah } & - & + & +\end{array}$

\begin{tabular}{|c|c|c|c|c|}
\hline \multicolumn{2}{|c|}{ Sample (B) Local } & \multirow{2}{*}{$\begin{array}{c}\text { Aspergillus_Niger } \\
+\end{array}$} & \multirow{2}{*}{$\begin{array}{c}\text { Fusarium spp } \\
+\end{array}$} & \multirow{2}{*}{$\begin{array}{c}\text { penicillium } s p p \\
-\end{array}$} \\
\hline $\mathrm{T}_{1}$ & Seria dan zang & & & \\
\hline $\mathrm{T}_{2}$ & Dan gashua & + & - & + \\
\hline $\mathrm{T}_{3}$ & Roman dan mazar & + & + & + \\
\hline $\mathrm{T}_{4}$ & Dan jino & + & + & - \\
\hline $\mathrm{T}_{5}$ & U T C & - & + & + \\
\hline
\end{tabular}

\section{Key (+) Present (Positive) \\ (-) Absent (Negative)}

The table 1 above indicates the fungal isolate identified on different sample (A), Tomatoes the result reveal that T1 and T2 had show positive reaction to all fungal species identified, T3 had Fusarium and penicillium species, T4 shown positive reaction to only Aspergillus niger while negative to Fusarium and Penicillium species, also the result are shown that T5 had two positive reaction of fungal spore (Fusarium and Penicillium species), while negative Aspergillus Niger.

However, the result shows that in sample (B) local cultivar reveals that two fungal isolate was identified on T1 that is Aspergillus niger and Fusarium spp. In T2 Aspergillus niger and penicillus spp, T3 shows all the three fungal isolate identified, T4 shows only negative reaction to Penicillium spp, T5 had shown the present of Fusarium spp and the penicillium spp, while negative to Aspergillus niger respectively. 
Table 2 : Mean disease index recorded on improved cultivars of tomatoes
Sample (Improve)
Disease Index (\%)

$\mathrm{T}_{1} \quad$ Rio grand

$\mathrm{T}_{2} \quad$ Tema

$\mathrm{T}_{3} \quad \mathrm{Ut}-82 \mathrm{~B}$

$\mathrm{T}_{4} \quad$ Roma vf

$\mathrm{T}_{5} \quad$ Roma savannah

CV

$\mathrm{SE} \pm$
$98.14 \pm 3.2^{\mathrm{a}}$

$93.10 \pm 2.9^{a b}$

$84.23 \pm 3.4^{b}$

$46.21 \pm 7.6^{c}$

$64.27 \pm 5.5^{b}$

24.56

2.689

The above result shown that there were significant differences at $\mathrm{P} \leq 0.05$ on the disease index recorded on different samples of tomatoes. The result show that $\mathrm{T} 1(98.14 \%)$ recorded the highest index followed by T2 with $(93.10 \%)$, while the least was recorded on T4 (46.21\%).

Table 3 : Mean disease index recorded on local cultivars of tomatoes

Sample (Local) Disease Index (\%)

$\mathrm{T}_{1} \quad$ Seria dan zang $\quad 97.23 \pm 1.4^{\mathrm{ab}}$

$\mathrm{T}_{2} \quad$ Dan gashua

$\mathrm{T}_{3} \quad$ Roman dan mazar

$\mathrm{T}_{4} \quad$ Dan jino

$\mathrm{T}_{5} \quad \mathrm{U} \mathrm{TC}$

CV

$\mathrm{SE} \pm$
$95.16 \pm 2.7^{\mathrm{b}}$

$100.0 \pm 0.0^{\mathrm{a}}$

$92.26 \pm 1.4^{\mathrm{c}}$

$96.14 \pm 2.7^{\mathrm{b}}$

35.63

3.549

The table above shown that there were significant differences at $\mathrm{P} \leq 0.05$ on the disease index recorded on different local samples of tomatoes. The result shown that highest disease index was recorded on T3 (100\%) fungal spore germinated, followed with T1 (97.23) and the least was recorded on T4 (92.26). 
Table 4 : Mean (SE士)of germination loss on different sample of improved tomatoes seed germinated on petri dish

\section{Sample (A)improved}

Germination loss (\%)

$\begin{array}{lll}\mathrm{T}_{1} & \text { Rio grand } & 1.3 \pm 0.7^{\mathrm{c}} \\ \mathrm{T}_{2} & \text { Tema } & 36.0 \pm 6.1^{\mathrm{a}} \\ \mathrm{T}_{3} & \text { UC-82B } & 28.7 \pm 12.3^{\mathrm{ab}} \\ \mathrm{T}_{4} & \text { Roma vf } & 14.7 \pm 5.9^{\mathrm{bc}} \\ \mathrm{T}_{5} & \text { Roma savannah } & 2.0 \pm 1.2^{\mathrm{c}} \\ \mathrm{CV} & & 70.54 \\ \mathrm{SE} \pm & & 6.73\end{array}$

The table above shows significance different at $\mathrm{P} \leq 0.05$ on germination loss tested in different cultivar of improve tomatoes on the petri dish.the result shows that highest germination loss was recorded on T2 (36.0\%), followed by T3 (28.7) and least germination loss was recorded on T1 and T5 with 1.3 and $2.0 \%$ respectively.

Table 5 : Mean ( $\mathrm{SE} \pm$ ) of germination loss record on local cultivar of tomatoes seed on Petri-dish Sample (B) Local Germination loss (\%)

$\begin{array}{llc}\mathrm{T}_{1} & \text { Seria dan zang } & 63.3 \pm 13.5^{\mathrm{a}} \\ \mathrm{T}_{2} & \text { Dan gashua } & 33.3 \pm 8.7^{\mathrm{cd}} \\ \mathrm{T}_{3} & \text { Roman dan mazar } & 58.0 \pm 4.2^{\mathrm{ab}} \\ \mathrm{T}_{4} & \text { Dan jino } & 36.0 \pm 4.0^{\mathrm{bc}} \\ \mathrm{T}_{5} & \text { UTC } & 11.3 \pm 3.3^{\mathrm{d}} \\ \mathrm{CV} & & 33.43 \\ \mathrm{SE} \pm & & 7.79\end{array}$

The table 5 above shows that there were significant differences at $\mathrm{P} \leq 0.05 \%$ on the germination loss on local cultivar of tomatoes seed grown on the Petri-dish. The highest germination loss was recorded on T1 (63.3\%), followed with T3 (58.0\%) and the least was recorded on T5 (11.39\%) respectively. 


\section{IV.CONCLUSION}

Based on the study it was concluded that T1(Rio grand) had highest number of disease index with (98.14) on the improved seed. The result also reveals that the highest number of disease index was recorded on T3(Roman dan mazar) with (100.0\%) in local cultivars the result also reveal that the highest germination loss was recorded on T1(Rio grand) with (1.3\%) in improve variety while on local cultivars T5(Utc) with (11.3\%) has the least germination loss respectively.

\section{RECOMMENDATIONS}

Based on study the following recommendation were made. Farmers should adopt the used of improve variety because it had least seed borne pathogen when compared with the local varieties. Further research will needed to carried out to evaluate the tomato seed with least seed borne disease. The quarantine control of seed borne fungi should be adopted also in other to prevent the movement of the pathogenic fungi from infested to non infested areas such countries to another countries, by restricting the transfer of seeds vegetative propagates plant and plant products.e.t.c.

\section{REFERENCES}

[1]. Abel-Mllek, A., Hemida, S. and Bagy., (2005). Studies on fungi associated with tomato fruits and effectiveness of some commercial fungicides against three pathogen. Mycopath., 130:198-16.

[2]. Hack, C. (2005). Fungicidal and growth regulatory effects of tebunazole on lin seed. Ann. Appl. Biol., 124: 22-23. Journal of Applied Biology.

[3]. Mortensen, C. N. and Mabagaa, R. B. (2012). Capacity enhancement $\mathrm{p}$ roject Tanzania.
[4]. Umesha, S. (2006).Occureneof bacteria canker in tomato fields of Karnataka and effect of biological seed treatment on diseases incidence. Crop protection 25, 275-832.

[5]. Walcott, RR, Gitaitis, RD and Castro, AC. (2003). Role of blossom in watermelon seed infestation by Acidovoraxavenae sub sp .Citrulli. Phytopathology 93: 548-3.

[6]. Watterson, Z. C. (2008). Disease the tomato crops.Edited by Atherton and Rudich.Champan and Hall Ltd. NY.p.461-462.

\section{Cite this article as :}

Shehu I. B., Kharall A., Makinta B., " Identification of Tomato Seed Pathogens (Fungi) of Different Cultivars and Varieties in Maiduguri Borno State, International Journal of Scientific Research in Science, Engineering and Technology(IJSRSET), Print ISSN : 2395-1990, Online ISSN : 2394-4099, Volume 8, Issue 3, pp.549554, May-June-2021. Available at doi : https://doi.org/10.32628/IJSRSET21842 Journal URL : https://ijsrset.com/IJSRSET21842 